\title{
Introduction
}

\section{Resilience, Adaptive Peacebuilding and Transitional Justice}

\author{
Janine Natalya Clark and Michael Ungar
}

Since the idea for this book first took shape, the world has fundamentally changed. The shocks and stressors of the COVID-19 pandemic have affected all aspects of life and powerfully overturned the 'normality' that once was. As Walsh (2020: 899) notes:

$[\mathrm{M}]$ any families are experiencing an ongoing, pervasive sense of loss: the tragic deaths and threatened loss of loved ones; the loss of physical contact with family members and social networks; the loss of jobs, financial security, and livelihoods; the loss of pre-crisis ways of life and threatened loss of hopes and dreams for the future; and the loss of a sense of normalcy in shattered assumptions about our lives and connections with the world around us.

The pandemic has inevitably triggered a wealth of new research, particularly within the fields of medicine, epidemiology and vaccine studies. Due to the immense challenges posed by this coronavirus, and its multi-systemic effects, some scholars have also examined it through a resilience lens (see, e.g., Chen and Bonanno, 2020; Labrague and De los Santos, 2020; Legido-Quigley et al., 2020; Shanahan et al., 2020). Indeed, Barzilay et al. (2020) argue that ' $\mathrm{t}]$ ]he rapid spread of COVID-19 creates a unique opportunity to evaluate resilience in the face of a single global adversity'. The pandemic and some of the research surrounding it have thus added to an already extremely rich and vast body of scholarship addressing and exploring the theme of resilience.

Referring to the concept's 'effortless ability to move across the natural, social and psychological sciences', Duffield (2012: 480) underlines that resilience is 'multidisciplinary in a radical sense of the term, while also enjoying epic scalability'. In short, '[i]t can be invoked at the level of organisms and individual psychology, is found in natural habitats and social institutions, and forms a vital property of the built environment' (Duffield, 2012: 480). This diversity is well captured by Xu and Kajikawa (2017), whose citation network analysis 
shows ten overlapping domains of resilience scholarship, with clusters of papers appearing in fields as different as marine science and psychiatry. While the most popular discourse on resilience remains in the psychological sciences, the concept of adaptation under adversity is finding relevance in many other disciplines as well. The COVID-19 pandemic is making resilience research even more relevant, especially emerging science which is showing that the robustness of one system can dramatically affect the capacity of cooccurring systems to survive and thrive (Brown, 2016). Just as individual lifestyles and biology make us more or less susceptible to the virus, our trust in institutions like public health and accommodations by our workplaces are also having a dramatic effect on our ability to weather the changes we have all experienced.

\section{RESILIENCE, VIOLENCE AND CONFLICT}

Notwithstanding the aforementioned 'effortless ability' of the resilience concept to move across and between different fields and disciplines, it is striking that resilience has received only limited attention in the context of communities and societies that have experienced conflict, violence and large-scale human rights abuses. Concepts such as reconciliation and reconstruction are given far more prominence. Some scholars, however, have discussed the resilience of particular groups in war situations. These include children (Betancourt and Khan, 2008; Fernando and Ferrari, 2011; Halevi et al., 2016; Masten and Narayan, 2012), former prisoners of war (Freeman et al., 2006; Gold et al., 2000; Jones and Wessely, 2010) and war veterans (Elliott et al., 2017 Portnoy et al., 2018; Vogt and Tanner, 2007). More broadly, others have underlined the resilience of entire populations dealing with a multitude of conflict- and violence-related stressors. Focusing on Islamic State violence against the Yezidi minority in northern Iraq, for example, Isakhan and Shahab (2020: 18) underscore that " $[\mathrm{i}] \mathrm{n}$ returning to their traditional homelands and reconstructing their heritage sites, the Yezidi people have demonstrated remarkable resistance and resilience'. Focused on the Syrian war that began in 2011, and particularly on the city of Homs which was under siege for three years from 2012, Azzouz (2019: 108) argues that 'despite mass destruction and monumental displacement, citizens in conflict zones such as this have shown extraordinary levels of resilience and have created mechanisms and strategies to carry on with their everyday lives'.

While such research is important, two particular points should be underlined. The first is that the use of adjectives like 'remarkable' and 'extraordinary' is problematic because these words convey the idea that those who 
demonstrate resilience are somehow exceptional. Not only does this sit uneasily with the argument that 'resilience is common' (Bonanno, 2004: 26; see also Barber, 2013: 463; Masten, 2014), but it also feeds the normative criticism that resilience discourse places an unfair burden on individuals (Ungar, 2011). Howell and Voronka (2012: 4), for example, maintain that 'getting citizens to be resilient in the face of challenges is not only cheap (in that it diverts patients out of public health care systems, in favour of self-help and positive thinking), it is also about aspiring to create a resilient citizenry, able to cope with uncertainty'.

The second, broader issue is that, because discussions about resilience in the context of conflict and violence often have a strong individual focus, this necessarily decontextualises the very meaning of resilience - and thus detracts from the wider social ecologies that have a crucial role to play in fostering and sustaining resilience. Discussing two Pakistani women who were raped, Haeri (2007: 299) underlines: 'The cases of Rahila and Veena highlight multiple sources within their immediate community environment that assisted each woman to empower herself, to engage with families and friends, to seek solace from religion and politics, and to pursue an individually meaningful course of action to overcome unspeakable brutality.' The crucial point is that, in societies overcoming the shocks and stressors of violence, an individual-centred resilience discourse can deflect from the vital importance of building and fostering systems that need to function optimally for people to experience psychosocial growth under adversity. Contrary to neoliberal critiques, resilience is not about encouraging 'people to individually respond to collective instabilities and uncertainties' (Garrett, 2016: 1920; see also Brassett and Vaughan-Williams, 2015; Chandler, 2013; Joseph, 2013), but, rather, about developing and strengthening vital protective factors and resources within individuals' social ecologies (Ungar, 2011).

This unique edited volume is the first to explore the concept of resilience across a range of different societies that have experienced - and in some cases are continuing to experience - mass violence linked to war and conflict (and related structural violence). The eight case study chapters - BosniaHerzegovina, Rwanda, Uganda, Bangladesh, Cambodia, Colombia, Guatemala and Palestine - provide rich conceptual and empirical analyses of resilience, what it 'looks' like and how it is expressed. They include stories of individual resilience, but ultimately they tell a bigger story about resilience, systems and the multi-systemic legacies of mass violence. Three central strands run through the book, weaving together the different chapters. These are its conceptualisation of resilience as a multi-systemic concept, its emphasis 
on transitional justice and its discussions of how transitional justice processes might contribute to adaptive peacebuilding.

\section{RESILIENCE AS A MULTI-SYSTEMIC CONCEPT}

While the most persistent definition of resilience comes from earlier studies of psychological invulnerability (Anthony, 1987) (with some of those studies originating in contexts of war - see, for example, Cohler, 1991), the past two decades have seen a transformation in how the term is used. No longer understood as an attribute of an individual, human resilience is now studied as a dynamic process in which individuals and their environments interact to optimise human potential (Ungar, 2018).

This change from person-centric definitions of resilience focused on individual capacities towards more complex social-ecological (and processual) definitions has taken scholars decades to validate. Resilience can now be defined as 'the capacity of both individuals and their environments to interact in ways that optimize developmental processes' (Ungar, 2013: 256). This definition informs a new agenda for research, and one that is attentive to the promotive and protective mechanisms that support positive change at multiple systemic levels. For example, Mahdiani et al. (2020) have shown that even in communities undergoing massive social disruption, as is occurring for communities dependent upon the oil and gas extraction and processing industries, sustainability is a reflection of each community's capacity to anticipate change and build the institutional responses that facilitate individual coping amid changes to economic conditions tied to the price of oil. It is studies like this that are driving greater interdisciplinarity in the field of resilience scholarship (a trend that is abundantly evident in this volume) and providing clues to the following questions: (1) How does the resilience of one system at one scale (e.g. biological, psychological, social, political, economic, environmental) influence the resilience of other systems? (2) Are there similarities and differences in the processes, mechanisms and patterns associated with resilience across systems and at different scales? (3) How can a multi-systemic understanding of resilience inform changes to policy and practice that will improve the well-being of humans, societies and ecosystems?

Reflecting this understanding of resilience, our first aim, then, is to show that exploring resilience, and more specifically some of the multi-level resources and protective factors that help to buffer the impact of violent and traumatic shocks and stressors, can offer new insights into societies that have experienced mass violence and the types of help and support that they might need. Awareness of the diversity of forms that resilience can take in these 
societies, and of how individuals and communities - in interaction with their wider social ecologies - utilise and develop their own resilience resources is, in turn, an important part of moving away from template approaches to 'building peace'.

\section{TRANSITIONAL JUSTICE}

The second strand of focus on resilience is to explore its links to transitional justice, which the United Nations (UN) (2010) has defined as 'the full range of processes and mechanisms associated with a society's attempt to come to terms with a legacy of large-scale past abuses, in order to ensure accountability, serve justice and achieve reconciliation'. To date, the ever-expanding field of transitional justice has largely overlooked the concept of resilience. However, some scholars have started to address this gap, particularly drawing attention to various inter-connections and linkages between transitional justice and resilience.

Kastner (2020: 372), for example, points out that ' $[\mathrm{b}]$ oth transitional justice and resilience are concepts that are employed in the context of seemingly intractable problems that are encountered and that need to be dealt with, managed or adapted to'. Wiebelhaus-Brahm (2017: 142), for his part, underlines that '[i]ntentionally or not, transitional justice is one policy intervention that likely affects the resilience of human societies'. Most obviously, the atrocities and human rights violations that create a need for transitional justice interventions constitute major shocks and stressors across entire social systems. Addressing the legacies of these crimes and abuses, transitional justice processes necessarily affect - as part of their own legacies - the long-term impact of the past and how individuals, communities and societies deal with it. In this way, transitional justice can potentially promote resilience. It may do so, for example, by "enhancing the effectiveness and legitimacy of international rules and procedures, thereby (re)building connections between authorities and the masses' (Wiebelhaus-Brahm, 2017: 154). Through institutional reforms and the re-establishment of the rule of law, transitional justice can also contribute to providing 'the kinds of public goods that enhance resilience' (WiebelhausBrahm, 2017: 154).

Conversely, transitional justice processes might also have the opposite effect. Resilience is quintessentially a relational concept. According to Luthar (2006: 780), '[r] esilience rests, fundamentally, on relationships'; Hayward (2013) maintains that 'human resilience is best understood as the interrelationships among the individuals and their community, environment, and social institutions'; and Hartling (2008: 53) underlines that 'resilience is all 
about relationships' (emphasis in the original). Transitional justice processes can thus potentially undermine resilience when they polarise communities and contribute to entrenching ethnic and social divides. On this point, Leebaw (2008: 96-97) notes that " $\mathrm{b}$ ] ecause truth commissions and criminal tribunals investigate extremely divisive and violent histories, they have often been viewed as obstacles to reconciliation and charged with "opening old wounds", generating political instability and interfering with forward-looking political change'.

Furthermore, transitional justice processes have traditionally given little attention to socio-economic and structural injustices, including those related to colonialism (see, e.g., Balint et al., 2014; Maddison and Shepherd, 2014; Mullen, 2015). If transitional justice overlooks these injustices, it thereby also neglects the importance of 'resilient infrastructures so that considerations of social justice can be addressed more adequately' (Doorn et al., 2019: 119). In this regard, Kastner (2020: 374) suggests that resilience thinking can actually pose risks for transitional justice; the latter typically 'does not seek to or allow the individuals and communities most immediately concerned by the violence in question to challenge the factors that enabled and perpetuated the violence in the first place'. Taking a different view, however, Duthie (2017: 12) maintains that " $\mathrm{n}$ ]otions such as development, resilience, and transformation are useful in thinking about the extent to which transitional justice processes are affected by and can at the same time address root causes and contribute to broad change'. He also accentuates what he calls 'the bi-directional relationship between contexts of social and economic structures and transitional justice' (Duthie, 2017: 24).

Part of what makes this book highly novel is its in-depth analysis of the relationship between resilience and transitional justice. Going beyond the question of whether and how transitional justice processes might contribute to or undermine resilience, it surveys some of the ways that these processes shape and affect resilience - across multiple systemic levels - in practice. For example, a rights-based approach to community empowerment in a postcolonial world, like that explored by Atallah et al. (2019) in Chile and Palestine, forces us to consider the need for significant changes to social relations and government structures if populations that have experienced historical oppression are to recover and transform. Anything less multisystemic runs the risk of blaming populations that have been starved of resources for their challenges, while doing little to resource them sufficiently to succeed in contexts of structural disadvantage.

For these reasons, there are important synergies and a number of discordances - largely unexplored to date - between resilience and key transitional 
justice goals, including peace and reconciliation. Certain types of resilience, for example, can work against reconciliation. Discussing the issue of political reconciliation between Indigenous peoples and settler nations, Whyte (2018: 287 ) asserts that 'For at least some Indigenous persons, it's not unreasonable at all to see settler attempts at reconciliation, from apologies to truth and reconciliation commissions, as new forms of the same old system that portrays indigenous peoples as parasites who clamour for aid and special accommodations from benevolent hosts'. He further argues that ' $\mathrm{t}$ ] he maintenance of this illusion is itself the operation of a parasitic system - a very resilient parasitic system' (Whyte, 2018: 287). The broader point in this regard is that 'undesirable states, systems or institutions [can] also be highly resilient - and resilient systems can be highly unequal with the benefits from such resilience unevenly distributed' (Walsh-Dilley and Wolford, 2015: 174). In this case, as with all scholarly investigations of resilience, one has to ask if the resilience of one system comes with a trade-off - the vulnerability of another co-occurring system (Folke, 2006).

To take a more positive example, Ungar (2013: 258$)$ argues that the more that environments 'make available and accessible the resources that promote wellbeing', the more likely individuals are 'to engage in processes associated with positive development such as forming secure attachments, experiencing selfesteem, engaging in expressions of personal agency, and meaningful employment'. In other words, if people are not worrying about basic life necessities such as food, housing and medical care, they can potentially invest more including emotionally - in transitional justice processes. As Millar (2011: 529) discusses in the context of Sierra Leone's Truth and Reconciliation Commission (TRC), 'the very nature of the deprivation the average resident of Makeni [the town in which he conducted fieldwork] experiences on a dayto-day basis limits the applicability of such mechanisms of justice at any given time. Life is experienced as flowing and ongoing, and so are infringements upon rights'.

In focusing on the relationship between resilience and transitional justice, our starting premise for this volume is that ' $\mathrm{r}$ ] esilience arguably offers a fresh perspective on transitional justice' (Kastner, 2020: 369). In their research on Colombia, for example, Nussio et al. (2015: 354) found that 'differences between victims and nonvictims are small when it comes to attitudes toward several aspects of transitional justice, like punishment of perpetrators, truth seeking, historical memory and reparations'. They accordingly underline the need for further research examining 'to what extent the development of an institutional framework and budget addressing the needs of victims in itself provides an incentive for the differentiation of victims and the development of 
a victim-centered agenda by hundreds of fledgling victims' organizations, beyond actual differences in political preferences and opinions between victims and other groups' (Nussio et al., 2015: 354). The bigger issue is that adding a resilience lens underscores the importance of focusing not just on direct victims (or 'non-victims') of violence and human rights abuses, but also on their wider social ecologies.

This, in turn, is directly linked to the book's second core aim. It seeks to demonstrate that thinking about resilience as a multi-systemic concept (see Ungar, 2021) opens a space for developing new ways of theorising and operationalising transitional justice that are more responsive to the wider social ecologies that link individuals and communities to their environments - and to the broader systems within which transitional justice work takes place (Clark, 2020a, 202ob). The chapters explore whether transitional justice processes - including criminal trials, TRCs and reparations - have shaped resilience in various societies that have experienced mass violence. Windle (2011: ${ }_{165}$ ) argues that, in order to be most effective, interventions should address the 'dynamic interplay' across different system levels, rather than focus only on developing individual strengths. This book explores the 'dynamic interplay' of different transitional justice processes within complex social systems. More broadly, the chapters reflect on some of the ways that transitional justice might potentially contribute to resilience. Central to this particular discussion is the book's third key strand.

\section{ADAPTIVE PEACEBUILDING}

de Coning (2018: 301) reflects that " $\mathrm{t}$ ] he era of liberal idealism and interventionism is on the ebb and in its place we are witnessing a pragmatic turn in peacebuilding'. As one illustration, the UN has embraced a 'new sustaining peace concept' - as part of its 'Sustaining Peace' agenda (see UN, n.d.) according to which the role of the organisation is 'to assist countries to sustain their own peace processes by strengthening the resilience of local social institutions, and by investing in social cohesion' (de Coning, 2018: 301). ${ }^{1}$ de

1 In Resolution 7o/262, for example, the UN General Assembly (2016: para. 3) - in its review of UN 'peacebuilding architecture' - reaffirmed, inter alia, 'the importance of national ownership and leadership in peacebuilding, whereby the responsibility for sustaining peace is broadly shared by the Government and all other national stakeholders'. It also underlined 'the importance, in this regard, of inclusivity in order to ensure that the needs of all segments of society are taken into account' (UN General Assembly, 2016: para. 3). The UN Security Council (2016) echoed these points in its Resolution 2282. In 2018, in a report pursuant to these two Resolutions, the UN Secretary-General emphasised: 'My aim is to forge a common vision and common systems and capacities across the United Nations to consistently and adequately 
Coning (2018: 304-305) proposes adaptive peacebuilding specifically as one approach to operationalise this sustaining peace concept.

As he defines adaptive peacebuilding, there are three key concepts that inform it - namely complexity, resilience and local ownership. Complexity theory is quintessentially about complex systems and, when applied to peacebuilding, it underscores the fact that peacebuilding is a multi-systemic endeavour that both engages and extends across myriad systems. These complex systems naturally adjust to shocks and stressors: 'In complex systems, the elements react to stimuli in non-linear ways and this enables the system to adapt and evolve, so that it can find new ways to pursue its goals and reach its objectives' (de Coning, 2016: 173). Enhancing these adaptations is a crucial part of fostering sustainable peace. Fundamentally, 'Peacebuilding in the sustaining peace context is about stimulating those processes in a society that enable self-organization and that will lead to strengthening the resilience of the social institutions that manage internal and external stressors and shocks' (de Coning, 2018: 307).

Local ownership and inclusivity are crucial in this regard. Complexity theory makes it clear that there are no simple or clear-cut solutions to complex problems, and, hence, "[o]ne should, therefore, not attempt to solve such problems with determined-design methodologies aimed at definitively diagnosing a problem and prescribing a solution' (de Coning, 2018: 313). Rather, an adaptive peacebuilding approach entails working closely with affected communities on the ground 'to collaboratively develop self-awareness of the causes and drivers of conflict in the system' and, thus, 'to ultimately support the emergence of local resilient social institutions that can self-manage future tensions' (de Coning, 2018: 313).

The book's third principal aim is to further develop the idea of adaptive peacebuilding, both conceptually and empirically. The chapters in this volume analyse whether and how transitional justice processes themselves can contribute to adaptive peacebuilding in the sense of helping to foster adaptive capacity and resilience across complex systems that have experienced the shocks and stressors of war, conflict and large-scale violence. de Coning (2016: 177) underlines that 'Whenever we attempt to change something in a complex system, the system responds to our intervention in a number of ways'. In other words, transitional justice processes affect entire systems, and an important way of thinking about these multi-systemic effects is precisely to look at whether these processes can help societies 'to develop the resilience

support Member States in their endeavour to sustain peace and build resilient and prosperous nations in line with their commitments to leave no one behind' (UN, 2018: para. 4). 
and robustness they need to cope with and adapt to change' (de Coning, 2018: 316).

By linking resilience and adaptive peacebuilding, this volume helps to show that multi-systemic resilience can be operationalised in the everyday practices of how individuals and their communities interact and 'rebuild' their lives. Methodologically, this volume is innovative as scholars develop the tools to investigate change across systems that occur at the same time or sequentially. In the field of transitional justice, this means paying as much attention to cultural traditions and attitudinal shifts (individual psychological systems) as to people's familial and community relationships and the structures and institutions tasked with delivering 'justice' (Betancourt, 2008). The chapters throughout this volume are, therefore, illustrative of both the complexity of these interacting systems and the detailed research required to critically examine resilience in relation to individuals and societies that have experienced the shocks and stressors of conflict and large-scale violence.

\section{CONTENT SUMMARY}

The book is divided into two parts. The first part, Concepts and Relationships, lays the conceptual foundations, sets out the book's approach to resilience and discusses the linkages between the three core strands of resilience, transitional justice and adaptive peacebuilding. The chapter by Michael Ungar explores broadly the concept of multi-systemic resilience and its relevance to the field of transitional justice. The concept of resilience is best understood as a process whereby individual capital and social capital interact in ways that create optimal outcomes in stressed environments. As a process, Ungar explains that resilience can look very different in different contexts, with any single system (including systems that promote social justice, human rights and enforce laws) showing patterns of persistence, resistance, recovery, adaptation or transformation depending on the resources each system has available to support change. Ungar's chapter explores these processes and how they affect systems simultaneously at multiple levels. This understanding of resilience as a multi-systemic concept can help to explain how systems affected by transitional justice (both judicial and non-judicial) respond to stressors, in turn shaping individual, community and institutional responses. Ungar uses brief case examples to show how resilience changes depending on a population's exposure to extreme forms of potentially traumatising events, such as war, forced migration, genocide and chronic economic disruption. In doing so, his chapter positions resilience as a concept that can be integrated into the field of transitional justice. 
Wendy Lambourne's chapter shows what this integration might look like, setting the stage for an integration of concepts and a bridge between different areas of research. She explores how resilience thinking can contribute to the transformative potential of transitional justice processes, and how these processes can foster and deepen our understanding of both resilience and adaptive peacebuilding. The chapter examines how key transitional justice processes - namely criminal trials, truth commissions and reparations - can aid societal resilience, supporting resilient social structures, which, in turn, can improve individual capacities to cope in the aftermath of social shocks and violence. The chapter also discusses how building resilient communities is a logical consequence of more inclusive facilitated justice and participation (core processes of both resilience and transitional justice), along with healing and reconciliation. As a challenge to conventional understandings of transitional justice and its politico-legal, state-based, backward-looking framework, Lambourne argues that resilience thinking supports a greater focus on psychosocial, community-based, forward-looking approaches to transitional justice, consistent with the transformative turn in the field.

The second part of the book, Empirical Case Studies, examines resilience, transitional justice and adaptive peacebuilding through the lens of eight different country studies. In varied and unique ways, all of the chapters address the following four questions:

1. What does resilience, conceptualised systemically and ecologically, look like in societies that have experienced mass atrocities and collective violence?

2. What are the multi-systemic factors and processes that have helped individuals and communities to rebuild and positively adapt to shocks and stressors?

3. What role, if any, have different transitional justice processes played directly or indirectly - in fostering resilience in these societies?

4. How can transitional justice work aid adaptive peacebuilding?

Janine Natalya Clark's chapter focuses on Bosnia-Herzegovina (BiH), and more specifically on the ethnically mixed village of Ahmići. On 16 April 1993, a massacre in the village - at the height of the Bosnian war - resulted in the deaths of 116 Bosniaks. Drawing on fieldwork conducted in July 2019, Clark explores how individuals in Ahmići frequently demonstrate everyday resilience, despite suffering huge losses. However, she maintains that Ahmići cannot be accurately described as a resilient community - the sum of its parts - because it has not dealt with what happened in 1993 as a community. A major reason for this is that multiple systemic factors - including the 
persistence of ethnic divisions in $\mathrm{BiH}$ and the related demands of 'enmeshed cohesion' (Winton, 2008) - have not allowed the community to come together as one and to rebuild crucial social connections. Exploring the work of the International Criminal Tribunal for the former Yugoslavia (ICTY), she shows that its trials further entrenched ethnic divisions in Ahmići; and, in this way, they undermined the function of both the community and, systems of justice as potential resilience resources. Ultimately, her chapter calls for a socialecological reframing of transitional justice that gives greater attention to the complex systems that necessarily shape what transitional justice processes can achieve on the ground; and, in this regard, she explores a crucial nexus between transitional justice and adaptive peacebuilding.

Jennie E. Burnet's chapter is the first of two African case study chapters. Focused on the 1994 Rwandan genocide and its aftermath, Burnet strongly emphasises the tensions between resilience models of recovery, adaptive peacebuilding and transitional justice. On one hand, ordinary Rwandans and civil society leaders have adapted to the trauma and shocks of the Rwandan genocide by drawing on cultural resources, including religious beliefs and social customs. According to her, "These ad hoc processes of getting by, which emerged in the wake of the genocide, can be understood as forms of resilience and adaptive peacebuilding where people adapt to new circumstances out of necessity rather than through formal state or NGO intervention'. On the other hand, some national peacebuilding and reconciliation efforts in Rwanda have undermined and worked against adaptive peacebuilding efforts at the grassroots level. In this way, political processes that have created the appearance of stability and resilience have, in fact, sown the seeds for future instability and new divides. These same political factors have also permeated transitional justice work in Rwanda, including the Gacaca courts. If, in the long term, these courts ultimately increased stability (and, by extension, resilience), they did so by further consolidating and reinforcing the political dominance of the Rwandan Patriotic Front (RPF). In other words, 'resilience' in Rwanda has come at a significant political cost, marginalising the local ownership dimension of adaptive peacebuilding.

Uganda is the book's second African case study. The chapter authors, Philipp Schulz and Fred Ngomokwe, focus on survivors' groups as 'an underutilised element of transitional justice and peacebuilding at the local level'. Drawing on their fieldwork in northern Uganda, and exploring some of the many ways that survivors' groups offer support, Schulz and Ngomokwe argue that these groups facilitate 'a local ecology of resilience'. They do so, inter alia, by creating a space for survivors to support each other, to share their experiences and deal with them in locally owned ways and, by extension, to (re-)gain 
a sense of communality and social belonging. Particularly in the case of male survivors of conflict-related sexual violence, moreover, these groups can enable survivors to renegotiate their gender identities and to develop new understandings of masculinity. In this way, the chapter links survivors' groups with adaptive peacebuilding. It is significant in this regard that the formation of these groups reflects the absence of effective measures at the state level to address individuals' experiences of suffering and harm. This, in turn, highlights an interesting contrast to Rwanda, where heavy state intervention has undermined adaptive peacebuilding. Schulz and Ngomokwe further demonstrate that adaptive peacebuilding within survivors' groups has wider socialecological implications, carrying over into survivors' relations with their families and communities. The chapter thus strongly accentuates the relational and communal dimensions of resilience.

Nayanika Mookherjee's chapter addresses the use of sexual violence during the war in Bangladesh in 1971. Six days after the war ended, the new government publicly designated women who had suffered sexual violence as 'birangonas' or war heroines. This is not, however, the dominant image that has prevailed. Discussing the Bangladesh War Crimes Tribunal, as the main example of (belated) transitional justice in the country, Mookherjee argues that its work represents an attempt 'to keep the wounds of 1971 open'. In this way, the Tribunal contributes to a 'resilient' multi-systemic process that upholds the 'horrific figure of the birangona'. Mookherjee powerfully challenges this image - captured in 'That birangona hair photograph' by Naibuddin Ahmed. Drawing on ethnographic research, she rejects a narrow framing of conflict-related sexual violence that elevates concepts such as silence, shame, honour and stigma. Rather, she tells a more complex story of generative resilience, of the different ways that birangonas (and their families) have dealt with the violence of rape, of how these women refused government attempts to "marry them off. Ultimately, she demonstrates that systemic factors such as patriarchy need not restrict expressions of resilience. Rather, they create new possibilities for how resilience might be articulated and framed. Generative resilience by itself, however, attests to a broader set of systemic failures that fundamentally undermine adaptive peacebuilding. Mookherjee thus cautions against an overemphasis on resilience when past injustices have not been resolved.

The book's second Asian case study chapter focuses on post-Khmer Rouge Cambodia. Timothy Williams examines resilience from two angles. First, he explores how intersecting political, legal and economic systems 'limit resilience and access to potential resources that could, in theory, support resilience'. However, he also emphasises that particular systemic dynamics can 
help to foster resilience. He uses the example of patronage networks, which essentially provide individuals with a route to access the resources they need. Second, Williams discusses whether and how transitional justice processes in Cambodia have contributed to resilience, focusing on the work of the country's main transitional justice mechanism - the Extraordinary Chambers in the Courts of Cambodia (ECCC). He argues that, while the ECCC has made some small contributions to resilience, including through establishing individual criminal responsibility for Khmer Rouge crimes, overall its work has done little to foster resilience. One of the key reasons, he suggests, is the heavy politicisation of the tribunal, underscoring the broader point that transitional justice necessarily takes place within a political context. According to Williams, what the example of Cambodia ultimately demonstrates is the very limited scope for transitional justice to contribute to adaptive peacebuilding when political elites essentially use and co-opt transitional justice processes for their own ends.

In the first South American case study chapter, Sanne Weber looks at Colombia and incorporates her fieldwork with former internally displaced persons (IDPs) and former guerrillas from the Revolutionary Armed Forces of Colombia (FARC). She explores how her research participants in both groups had found their own ways of dealing with the adversities and challenges they faced, including through making jokes. The salient theme in her chapter, however, is social resilience, as outlined in Ungar's chapter. Social resilience, she argues, 'enables individuals and communities to navigate and negotiate access to the resources they need, such as land and financial support'. She particularly emphasises organisation and collective struggle as examples of social resilience. While there has been significant transitional justice work in Colombia, which remains ongoing, Weber maintains that this has not contributed to social resilience. Indeed, it has had the opposite effect. She thus underscores the need - which picks up on points made by Jennie Burnet and by Philipp Schulz and Fred Ngomokwe - for transitional justice to "promote the capacity of survivors to organise themselves - as communities or groups of survivors - to protect and promote their own well-being'. She asserts that transitional justice has a role to play in fostering resilience and furthering adaptive peacebuilding by enabling and empowering communities to direct their own reconstruction processes, and by helping to revive and strengthen previous practices of active citizenship.

M. Brinton Lykes, Alison Crosby and Sara Beatriz Alvarez Medrano are the authors of the Guatemala case study. Their chapter discusses the resilience of Mayan women protagonists as they have engaged in transitional justice processes and organised in defence of their rights. It uses the protagonists' own 
understanding of resilience as 'resistance, persistence, permanence, strength and determination', and underlines that Indigenous resilience is quintessentially multi-systemic and relational, 'rooted in an integral, collective relationship of land-body-territory'. In this way, it demonstrates that the Mayan cosmovision disrupts Western dualisms - of nature and culture, human and nonhuman, knowing and being - which are linked to ongoing colonial violence. The authors underscore that transitional justice processes can potentially only contribute to resilience in Guatemala if they recognise historical injustices done to Mayan people and - consistent with adaptive peacebuilding - support locally owned processes aimed at repairing multi-systemic legacies of colonial harms, including harms done to bodies, land and people's cosmovision. This is a powerful example of what a social-ecological approach to transitional justice might look like. Mayan protagonists' ongoing demands for 'justice' that respects and acknowledges their own integrated plurivision are themselves important expressions of resilience. Lykes, Crosby and Alvarez also accentuate the imperative for transitional justice processes to create a space for what the Indigenous scholar Eve Tuck (2009) has termed 'desire-based frameworks' - as opposed to 'damage-based narratives' - that foreground agency and resilience.

Devin Atallah and Hana Masud's chapter is the final case study and addresses the complexities of resilience and transformative justice in Palestine. Their chapter shows that, in conditions marked by structural violence resulting from the legacies of colonisation, transformative justice is a far better option for social resilience than transitional efforts to adapt people to their circumstances. For Atallah and Masud, transformative justice offers an opportunity for collective re-envisioning that is grounded in Indigenous knowledges and social practices that emerge from below, rather than being imposed from above. This iterative transformative process, which is congruent with a multi-systemic conceptualisation of resilience, requires change across different systems (from the psychological to the political) at the same time. The chapter uses (counter-)stories to show what this resilience and transformative justice look like and the complexity that such work entails. Through deeply personal narratives, the authors share memories of their villages, their lands and their loved ones who were lost to annexation and incarceration. From these experiences, they draw out three decolonial enactments related to resilience, embodying themes of self-determination, radical coalitions and the everyday acts of love that move people forward under conditions of extreme oppression.

In the final chapter, Cedric de Coning reflects on how the chapters in this edited volume enrich, conceptually and empirically, the concepts of 
resilience and adaptive peacebuilding, and what they tell us about the complex ways that resilience manifests in different transitional and post-conflict contexts. Exploring three common themes (self-organisation, unintended consequences and process), one of the key points that he underlines - linked to the complexity dimension of adaptive peacebuilding is that transitional justice interventions take place within highly complex systems, meaning that unintended or undesired consequences are a very real possibility. This lends support to the case for a social-ecological reframing of transitional justice advocated in Clark's chapter on BiH. de Coning also underscores that resilience can manifest very unevenly in post-conflict and transitioning societies, potentially entrenching deeper structural injustices; and as Burnet and Williams discuss in their chapters on Rwanda and Cambodia, respectively, 'resilient' systems can impede or restrict individual and community expressions of resilience. de Coning accordingly accentuates that resilience is not something that is inherently good or positive for the sorts of societies examined in this volume. Yet, what he also emphasises is that the use of a resilience lens offers new ways of thinking about transitional justice. The link with adaptive peacebuilding is not only about doing transitional justice in ways that support local ownership of the process but also about enhancing how complex systems respond and adapt to stressors.

\section{REFERENCES}

Anthony, E. J. (1987). Risk, vulnerability, and resilience: An overview. In E. J. Anthony and B. J. Cohler (eds.), The Invulnerable Child. New York: Guilford Press, pp. 3-48.

Atallah, D. G., Bacigalupe, G. and Repetto, P. (2019). Centering at the margins: Critical community resilience praxis. Journal of Humanistic Psychology, https://doi .org/10.1177\%2Foo22167818825305

Azzouz, A. (2019). A tale of a Syrian city at war: Destruction, resilience and memory in Homs. City 23(1), 107-122.

Balint, J., Evans, J. and Mcmillan, N. (2014). Rethinking transitional justice, redressing indigenous harm: A new conceptual approach. International Journal of Transitional Justice, 8(2), 194-216.

Barber, B. K. (2013). Annual research review: The experience of youth with political conflict - Challenging notions of resilience and encouraging research refinement. Journal of Child Psychology and Psychiatry, 54(4), 461-473.

Barzilay, R., Moore, T. M., Greenberg, G. M., DiDomenico, G. E., Brown, L. A., White, L. K., Gur, R. C. and Gur, R. E. (2020). Resilience, COVID-19-related stress, anxiety and depression during the pandemic in a large population enriched for healthcare providers. Translational Psychiatry, 10(291). 
Betancourt, T. S. (2008). Child soldiers: Reintegration, pathways to recovery and reflections from the field. Journal of Developmental and Behavioral Pediatrics, 29 (2), $138-41$.

Betancourt, T. S. and Khan, K. T. (2008). The mental health of children affected by armed conflict: Protective processes and pathways to resilience. International Review of Psychiatry, 20(3), 317-328.

Bonanno, G. A. (2004). Loss, trauma and human resilience: Have we underestimated the human capacity to thrive after extremely aversive events? American Psychologist, 59(1), 20-28.

Brassett, J. and Vaughan-Williams, N. (2015). Security and the performative politics of resilience: Critical infrastructure protection and humanitarian emergency preparedness. Security Dialogue, 46 (1), 32-50.

Brown, K. (2016). Resilience, Development and Global Change. New York: Routledge.

Chandler, D. (2013). International statebuilding and the ideology of resilience. Politics, $33(4), 276-286$.

Chen, S. and Bonanno, G. A. (2020). Psychological adjustment during the global outbreak of COVID-19: A resilience perspective. Psychological Trauma: Theory, Research, Practice and Policy, $12\left(\mathrm{~S}_{1}\right), \mathrm{S}_{51}-\mathrm{S}_{54}$.

Clark, J. N. (2020a). Beyond 'bouncing': Resilience as an expansion-contraction dynamic within a holonic frame. International Studies Review, https://doi.org/10 $.1093 /$ isr/viaao48

Clark, J. N. (2020b). Re-thinking memory and transitional justice: A novel application of ecological memory. Memory Studies, https://doi.org/10.1177\% $2 F_{1750698020959813}$

Cohler, B. (1991). The life story and the study of resiliency and response to adversity. Journal of Narrative and Life History, 1(2-3), 169-200.

de Coning, C. (2016). From peacebuilding to sustaining peace: Implications of complexity for resilience and sustainability. Resilience, 4(3), 166-181.

de Coning, C. (2018). Adaptive peacebuilding. International Affairs, 94(2), 301-317.

Doorn, N., Gardoni, P. and Murphy, C. (2019). A multidisciplinary definition and evaluation of resilience: The role of social justice in defining resilience. Sustainable and Resilient Infrastructure, 4(3), 112-123.

Duffield, M. (2012). Challenging environments: Danger, resilience and the aid industry. Security Dialogue, 43(5), 475-492.

Duthie, R. (2017). Introduction. In Duthie, R. and Seils, P. (eds.), Justice Mosaics: How Context Shapes Transitional Justice in Fractured Societies. New York: International Center for Transitional Justice, pp. 8-38.

Elliott, T. R., Hsiao, Y. Y., Kimbrel, N. A., Meyer, E., DeBeer, B. B., Gulliver, S. B. Kwok, O. M. and Morissette, S. M. (2017). Resilience and traumatic brain injury among Iraq/Afghanistan war veterans: Differential patterns of adjustment and quality of life. Journal of Clinical Psychology, 73(9), 1160-1178.

Fernando, C. and Ferrari, M. (2011). Spirituality and resilience in children of war in Sri Lanka. Journal of Spirituality in Mental Health, 13(1), 52-77.

Folke, C. (2006). Resilience: The emergence of a perspective for social-ecological systems analyses. Global Environmental Change, 16(3), 253-267.

Freeman, T., Kimbrell, T., Booe, L., Myers, M., Cardwell, D., Lindquist, D. M., Hart, J. and Komoroski, R. A. (2006). Evidence of resilience: Neuroimaging in former prisoners of war. Psychiatry Research: Neuroimaging, 146(1), 59-64. 
Garrett, P. M. (2016). Questioning tales of 'ordinary magic': 'Resilience' and neo-liberal reasoning. British Journal of Social Work, 46, 1909-1925.

Gold, P. B., Engdahl, B. E., Eberly, R. E., Blake, R. J., Page, W. F. and Frueh, B. C. (2000). Trauma exposure, resilience, social support and PTSD construct validity among former prisoners of war. Social Psychiatry and Psychiatric Epidemiology, 35, $36-42$.

Haeri, S. (2007). Resilience and post-traumatic recovery in cultural and political context. Journal of Aggression, Maltreatment and Trauma, 14(1-2), 287-304.

Halevi, G., Djalovski, A., Vengrober, A. and Feldman, R. (2016). Risk and resilience trajectories in war-exposed children across the first decade of life. The Journal of Child Psychology and Psychiatry, 57(10), 1183-1193.

Hartling, L. M. (2008). Strengthening resilience in a risky world: It's all about relationships. Women and Therapy, 31(2-4), 51-70.

Hayward, B. M. (2013). Rethinking resilience: Reflections on the earthquakes in Christchurch, New Zealand, 2010 and 2011. Ecology and Society, 18(4), 37.

Howell, A. and Voronka, J. (2012). Introduction: The politics of resilience and recovery in mental health care. Studies in Social Justice, 6(1), 1-7.

Isakhan, B. and Shahab, S. (2020). The Islamic state's destruction of Yezidi heritage: Responses, resilience and reconstruction after genocide. Journal of Social Archaeology, 20(1), 3-25.

Jones, E. and Wessely, S. (2010). British prisoners-of-war: From resilience to psychological vulnerability: Reality or perception. 2oth Century British History, 21 (2), $163-183$.

Joseph, J. (2013). Resilience as embedded neoliberalism: A governmentality approach. Resilience, 1(1), 38-52.

Kastner, P. (2020). A resilience approach to transitional justice? Journal of Intervention and Statebuilding, 14(3), 368-388.

Labrague, L. J. and De los Santos, J. A. A. (2020). COVID-19 anxiety among front-line nurses: Predictive role of organizational support, personal resilience and social support. Journal of Nursing Management, 28(7), 1653-1661.

Leebaw, B. A. (2008). The irreconcilable goals of transitional justice. Human Rights Quarterly, 30(1), 95-118.

Legido-Quigley, H., Asgari, N., Teo, Y. Y., Leung, G. M., Oshitani, H., Fekuda, K., Cook, A. R., Hsu, L. Y., Shibuya, K. and Heymann, D. (2020). Are high-performing health systems resilient against the COVID-19 pandemic? The Lancet, 395(10227), $848-850$.

Luthar, S. S. (2006). Resilience in development: A synthesis of research across five decades. In D. J. Cohen and D. Cicchetti (eds.), Developmental Psychopathology: Risk, Disorder and Adaptation. Hoboken, NJ: John Wiley \& Sons, pp. 739-795.

Maddison, S. and Shepherd, L. J. (2014). Peacebuilding and the postcolonial politics of transitional justice. Peacebuilding, 2(3), 253-269.

Mahdiani, H., Höltge, J., Theron, L. and Ungar, M. (2020). Resilience in times of economic boom and bust: A narrative study of a rural population dependent upon the oil and gas industry. Journal of Adult Development, https://doi.org/10.1007/s10804020-09363-z

Masten, A. S. (2014). Ordinary Magic. Resilience in Development. New York: Guilford Press. 
Masten, A. S. and Narayan, A. J. (2012). Child development in the context of disaster, war and terrorism: Pathways of risk and resilience. Annual Review of Psychology, 63, 227-257. Millar, G. (2011). Local evaluations of justice through truth telling in Sierra Leone: Postwar needs and transitional justice. Human Rights Review, 12, 515-535.

Mullen, M. (2015). Reassessing the focus of transitional justice: The need to move structural and cultural violence to the centre. Cambridge Review of International Affairs, 28(3), 462-479.

Nussio, E., Rettberg, A. and Ugarriza, J. E. (2015). Victims, nonvictims and their opinions on transitional justice: Findings from the Colombian case. International Journal of Transitional Justice, 9(2), 336-354.

Portnoy, G. A., Relyea, M. R., Decker, S., Shamaskin-Garroway, A, Driscoll, M., Brandt, C. A. and Haskell, S. G. (2018). Understanding gender differences in resilience among veterans: Trauma history and social ecology. Joumal of Traumatic Stress, 31(6), 845-855.

Shanahan, L., Steinhoff, A., Bechtiger, L., Murray, A. L., Nivette, A., Hepp, U., Ribeaud, D. and Eisner, M. (2020). Emotional distress in young adults during the COVID-19 pandemic: Evidence of risk and resilience from a longitudinal cohort study. Psychological Medicine, https://doi.org/10.1017/So03329172000241X

Tuck, E. (2009). Suspending damage: A letter to communities. Harvard Educational Review, 79(3), 409-428.

Ungar, M. (2011). The social ecology of resilience. Addressing contextual and cultural ambiguity of a nascent construct. American Journal of Orthopsychiatry, 81(1), 1-17.

Ungar, M. (2013). Resilience, trauma, context and culture. Trauma, Violence and Abuse, 14(3), 255-266.

Ungar, M. (2018). Systemic resilience: Principles and processes for a science of change in contexts of adversity. Ecology and Society, 23(4), 34.

Ungar, M. (2021). Multisystemic Resilience: Adaptation and Transformation in Contexts of Change. New York: Oxford University Press.

United Nations. (2010). Guidance note of the Secretary-General: United Nations approach to transitional justice. www.un.org/ruleoflaw/files/TJ_Guidance_Note_ March_2010FINAL.pdf (accessed 9 September 2020).

United Nations (2018). Peacebuilding and sustaining peace: Report of the SecretaryGeneral. https://undocs.org/a/72/707 (accessed 14 September 2020).

United Nations (n.d.). Sustaining peace. www.un.org/peacebuilding/tags/sustainingpeace (accessed 11 May 2020).

United Nations General Assembly. (2016). Resolution adopted by the General Assembly on 27 April 2016 - 70/262. Review of the United Nations peacebuilding architecture. www.un.org/en/development/desa/population/migration/generalas sembly/docs/globalcompact/A_RES_70_262.pdf (accessed 11 May 2020).

United Nations Security Council. (2016). Resolution 2282 (2016). https://undocs.org/S/ RES/2282(2016) (accessed 13 May 2020).

Vogt, D. S. and Tanner, L. R. (2007). Risk and resilience factors for posttraumatic stress symptomology in Gulf War I veterans. Journal of Traumatic Stress, 20(1), 27-38.

Walsh, F. (2020). Loss and resilience in the time of COVID-19: Meaning making, hope and transcendence. Family Process, 59(3), 898-911.

Walsh-Dilley, M. and Wolford, W. (2015). (Un)Defining resilience: Subjective understandings of 'resilience' from the field. Resilience, 3(3), 173-182. 
Whyte, K. P. (2018). On resilient parasitisms, or why I'm sceptical of indigenous/settler reconciliation. Journal of Global Ethics, 14(2), 277-289.

Wiebelhaus-Brahm, E. (2017). After shocks: Exploring the relationships between transitional justice and resilience in post-conflict societies. In: R. Duthie and P. Seils (eds.), Justice Mosaics: How Context Shapes Transitional Justice in Fractured Societies. New York: International Center for Transitional Justice, pp. 140-165.

Windle, G. (2011). What is resilience? A review and concept analysis. Reviews in Clinical Gerontology, 21, 152-169.

Winton, M. A. (2008). Dimensions of genocide: The circumplex model meets violentization theory. Qualitative Report, 13(4), 605-629.

$\mathrm{Xu}, \mathrm{L}$. and Kajikawa, Y. (2017). An integrated framework for resilience research: A systematic review based on citation network analysis. Sustainability Science, 13 (1), 235-254. 